The Chittagong Univ. J. B. Sci., Vol. 5(1 \&2):45-53, 2010.

\title{
HISTOPATHOLOGY OF THE INTESTINE OF CLARIAS BATRACHUS L. UNDER HEAVY METAL STRESS
}

\author{
SHAWKAT ARA BEGUM, QAMAR BANU AND BAHARUL HOQUE* \\ Department of Zoology, University of Chittagong, Chittagong-4331, Bangladesh
}

\begin{abstract}
Histopathological effect of three heavy metals- cadmium, chromium and mercury on intestine of Clarias batrachus L. was studied under laboratory condition. The common histopathological changes that took place under heavy metal exposure were disintegration of mucosal epithelium, hypertrophied epithelial cells, increased number of goblet cells, sloughed off epithelial cells and mucous in the lumen, degeneration of the connective tissue of sub-mucosa and hyperemic blood vessels. .Separation of mucosal epithelium, especially in the villi and increased goblet cells were prominent in Cd-exposed fish. Clumping of the epithelial cells at the base near the basement membrane was prominent in the case of the $\mathrm{Cr}$ - and $\mathrm{Hg}$-exposure. Connective tissue degeneration in the lamina propria and submucosa of the intestine and dilated blood vessels with congestion of blood were prominent in the $\mathrm{Cr}$ and $\mathrm{Hg}$ exposed fish.
\end{abstract}

Key words : Histopathology, mucosal epithelium, hypertrophy, goblet cell.

\section{INTRODUCTION}

In nature, heavy metals are present in very small concentration, but beyond certain low limit, they become highly toxic to living organisms. Indiscriminate disposal of wastes produced due to various anthropogenic activities are held responsible for the rise of heavy metal concentration in nature. Water receives heavy metals and an array of other pollutants through land drainage, industrial effluents, organic wastes, sewage sludge, etc. (Ching and Hongxiao 1985, Kay et al. 1986). Once dispersed in the biosphere, heavy metals can not be recovered or degraded. They become free in nature, accumulate in agricultural fields, and in organisms causing reduction of biodiversity, poor production, and many other anomalies (Badsha and Goldspink 1982, Singh 1988).

Among the metal toxicants cadmium, chromium and mercury, the heavy metals with which the present work deals, have been detected in many waterbodies of Bangladesh in relatively high concentrations (Anonymous 1998,

${ }^{*}$ Corresponding author 
Quraishi and Akhter 2005). The present work is an attempt to investigate the toxic effect of three heavy metals- cadmium $(\mathrm{Cd})$, chromium $(\mathrm{Cr})$ and mercury $(\mathrm{Hg})$ on the intestine of Clarias batrachus L.

\section{MATERIALS AND METHODS}

Fresh and live specimens of Clarias batrachus L. (average length $16 \pm 3$ $\mathrm{cm}$ and weight $70 \pm 5 \mathrm{~g}$ ) was bought from Chittagong city market and acclimatized for 7 days in $25 \mathrm{~L}$ aquarium in nonchlorinated tap water. Fish species were given oligochaetes, prawn and small pieces of Harpodon nehereus as food once a day, and water was changed at $24 \mathrm{~h}$ interval. Following it, 15 fish specimens in each $25 \mathrm{~L}$ aquarium were exposed to each sub lethal conc. of heavy metals $(\mathrm{Cd}-9 \mathrm{ppm}, \mathrm{Cr}-12 \mathrm{ppm}$ and $\mathrm{Hg}-0.3 \mathrm{ppm})$ for 28 days along with a control without heavy metal. Test fishes in the aquarium were fed once a day with a change of solution after each feeding.

Method of Humason (1961) was followed for histopathological study. At the end of the exposure period intestine from the metal exposed as well as control fishes were isolated, cleaned with physiological saline solution, cut into pieces and fixed in freshly prepared Bouin's fixative. After 24 hours tissues were transferred to $70 \%$ alcohol for preservation. For histological slide preparation tissues were dehydrated in graded alcohol, cleared in benzene and embedded in

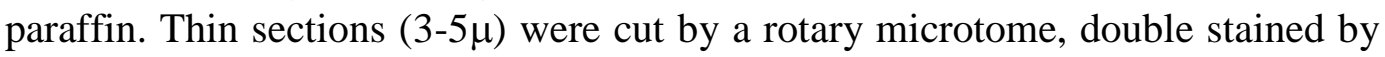
eosin-haematoxylin, mounted with DPX for examination under microscope. Photomicrographs were taken by Ricoh 35 mm SLR camera.

\section{RESULTS AND DISCUSSION}

In control specimen, the intestine wall of C. batrachus was composed of four layers viz, mucosa, submucosa, muscularis and serosa (Plate 1). The mucosa was thrown into prominent finger like projections forming villi. The mucosa was composed of columnar epithelium consisting of absorptive and mucous secreting cells or goblet cells. The submucosa, made up of loose connective tissue, was vascular and extended into the villi as lamina propria which formed the core of the villi. The muscularis was formed of the inner circular and the outer longitudinal layer of smooth muscle fibres. Serosa formed the outermost thin layer of flattened epithelial cells.

The common histopathological changes that took place under heavy metal exposure were, damages of the mucosal epithelium, detachment of epithelium 


\section{HISTOPATHOLOGY OF CLARIAS BATRACHUS INTESTINE UNDER METAL STRESS}

from the basal layer, especially at the tips of the villi, vacuolation in the epithelium, hypertrophy and degeneration of the mucosal epithelial cells (Plates 2-8).

Degeneration of epithelium and subepithelial tissues of the intestine was noted by Konar (1975) in the carp Labeo rohita and catfish Heteropneustes fossilis due to DDVP and phosphamidon pesticides, while Kabir and Begum (1978) noted lesion of villi, and necrosis of epithelial cells of the intestine of fish exposed to diazinon. Sastry and Gupta (1979) observed degeneration of intestinal villi in $H$. fossilis exposed to cadmium. Separation of the hypertrophied mucosal epithelium from the basement, especially in the villi was prominant in case of Cdexposed fish in the present experiment. Moitra and Sadhu (1982) while working with Channa striatus exposed to phosphamidon reported that the toxic agents induced damage to the mucous membrane and the basement layer of the intestine. All these findings fully agree with the findings of the present work. Test fish of the present work revealed derangement of the epithelial cells of the mucous membrane, rupture of the epithelial cells and formation of cluster by the distorted cells or nuclei at some places indicative of necrosis. The epithelial cells were hypertrophied with pyknotic nuclei and clear cytoplasm. Some degree of necrosis was also observed by Kabir and Begum (1978) in the intestine of fish exposed to diazinon. Clumping of the epithelial cells at the base near the basement membrane seemed to be a primary stage of rupturing or erosion of the epithelium from the basal layer. Such change was prominent in the case of the $\mathrm{Cr}$ - and $\mathrm{Hg}$-treated C. batrachus (Plates 4, 7). Virk et al. (1987) observed disappearance of the goblet cells in the pesticide exposed fish, Mystus tengara, which is contrary to the finding of the present work where increased number of goblet cells was noted in the mucous membrane of the $\mathrm{Cd}-, \mathrm{Cr}-$ and $\mathrm{Hg}$ - treated fishes which, however, corroborates with the findings of others (Annes 1976, Sastry and Gupta 1979, Sastry and Malik 1979, Jauhr and Kulshrestha 1983, Pandey et al. 1994). Crespo et al. (1986) in an investigation on intoxication due to dietary cadmium and lead, observed increased goblet cells and enlarged apical pits and suggested that heavy metal exposure triggers mucous cell activity and production of mucous as a protective measure from the irritating agents.

In the present study, connective tissue degenerations were noticed in the lamina propria and submucosa of the intestine. Such degenerative changes were prominent particularly in the $\mathrm{Cr}$ and $\mathrm{Hg}$ exposed fish (Plates $5-8$ ). Besides, dilated blood vessels with congestion of blood were also noticed in those fishes. 
BEUM ET AL.

The above findings corroborate with the results of earlier investigators (Konar 1975, Bengeri and Patil 1985, Virk et al. 1987, Begum et al. 2001). Crespo et al. (1986) observed oedematous epithelial and connective tissue, and dilated blood vessels in trout intestine due to cadmium exposure. They regarded those symptoms as response to the irritation of internal mucosa by the metal.

\section{REFERENCES}

ANNES, M. A. 1976. Intestinal pathology of fresh water teleost, Channa punctatus (Bloch) exposed to sub-lethal and chronic levels of three organophosphorus insecticides. Acta. Physiol. Lat. Am. 26: 63-67.

ANONYMOUS. 1998. Industrialization and industrial pollution. In: Bangladesh Environment: Facing the 21st century. (Ed., Gain, P.). SEHD, Dhaka, pp.165-185.

BADSHA, K. S. AND GOLDSPINK, C. R. 1982. Preliminary observations on the heavy metal content of four species of fresh water fish in NW England. J. Fish. Biol. 21: 251-256.

BEGUM, S. A., KHANAM, F. AND HOQUE, B. 2001. Effects of chromium on histological structures of different organs of Clarias gariepinus (Burchel). The Chittagong Univ. J. Sci. 25(1): 1-10.

BENGERI, K. V. AND PATIL, H. S. 1985. Histopathological changes induced by zinc in the intestine of fresh water fish Labeo rohita (Ham.). Matsya 11: $92-95$.

CHING, I. L. AND HONGXIAO, T. 1985. Chemical studies of aquatic pollution by heavy metals in China. In: Environmental inorganic chemistry. VCH Pub. Inc.

CRESPO, S., NONNOTTE, G., COLIN, D. A., LERAY, C., NONNOTTE, L. AND AUBREE, A. 1986. Morphological and functional alterations induced in trout intestine by dietary cadmium and lead. J. Fish. Biol. 28(1): 69-80.

HUMASON, L. G. 1961. Animal tissue technique. $2^{\text {nd }}$ ed. W. H. Freeman and Company. Sunfrancisco, U.S.A.

JAUHR, L. AND KULSHRESTHA, S. K. 1983. Histopathological changes induced by sub-lethal doses of endosulphan and carbyl in the intestine of Channa striatus. Indian J. Zool. 11:35-41.

KABIR, S. M. AND BEGUM, R. 1978. Toxicity of three organophosphorus insecticides to H. fossilis. Dhaka Univ. Stud. B. 26(1): 115-122. 
HISTOPATHOLOGY OF CLARIAS BATRACHUS INTESTINE UNDER METAL STRESS

\section{KAY, J., THOMAS, D. G., BROWN, H. V., CRYER, A., SHURBEN, D.,} SOLBE, J. F., DE, L. G. AND GARSNEY, J. S. 1986. Cadmium accumulation and protein binding patterns in tissues of the rainbow trout (Salmo gairdneri). Environ. Health Perspect. 65:133-139.

KONAR, S. K. 1975. Pesticides and aquatic ecosystems. Indian J. Fish. 22(1, 2): $80-85$.

MOITRA, S. K. AND SADHU, A. K. 1982. Effect of sub-lethal doses of phosphamidon on the alimentary system of the Murrel Channa striatus (Bi): 1 . Histopathological studies. J. Inland Fish. Soc. India 14(2):55-60.

PANDEY, B.N., MOHAMMAD, M.P., AND GEORGE, K.C. 1994. Histopathological alterations in liver and intestine of Liza parsia (Hamilton-Buchanon) in response to mercuric toxicity. J. Adv. Zool. 15: 18-24.

QURAISHI, S. B. AND AKHTER, S. 2005. Study of concentration of some toxic and essential elements in marine water, sediment and their impact on marine biota. J. Bangladesh Acad. Sci. 29(2): 163-171.

SASTRY, K. V. AND GUPTA, P. K. 1979. The effect of cadmium on the digestive system of the teleost fish, Heteropneustes fossilis. Environ. Res. 19: 221-230.

SASTRY, K. V. AND MALIK, P. V. 1979. Studies on the effects of dimecron on the digestive system of a freshwater fish, Channa punctatus. Arch. Environ. Contam. Toxicol. 8: 397-407.

SINGH, V.P. 1988. Toxic models in soil-plant systems with special reference to cadmium. Int. J. Ecol. Environ. Sci. 14: 185-197.

VIRK, S., KAUR, K. AND KAUR, S. 1987. Histopathological and biochemical changes induced by endrin and carbaryl in the stomach, intestine and liver of Mystus tengara. Indian J. Ecol. 14 (1): 14-20. 


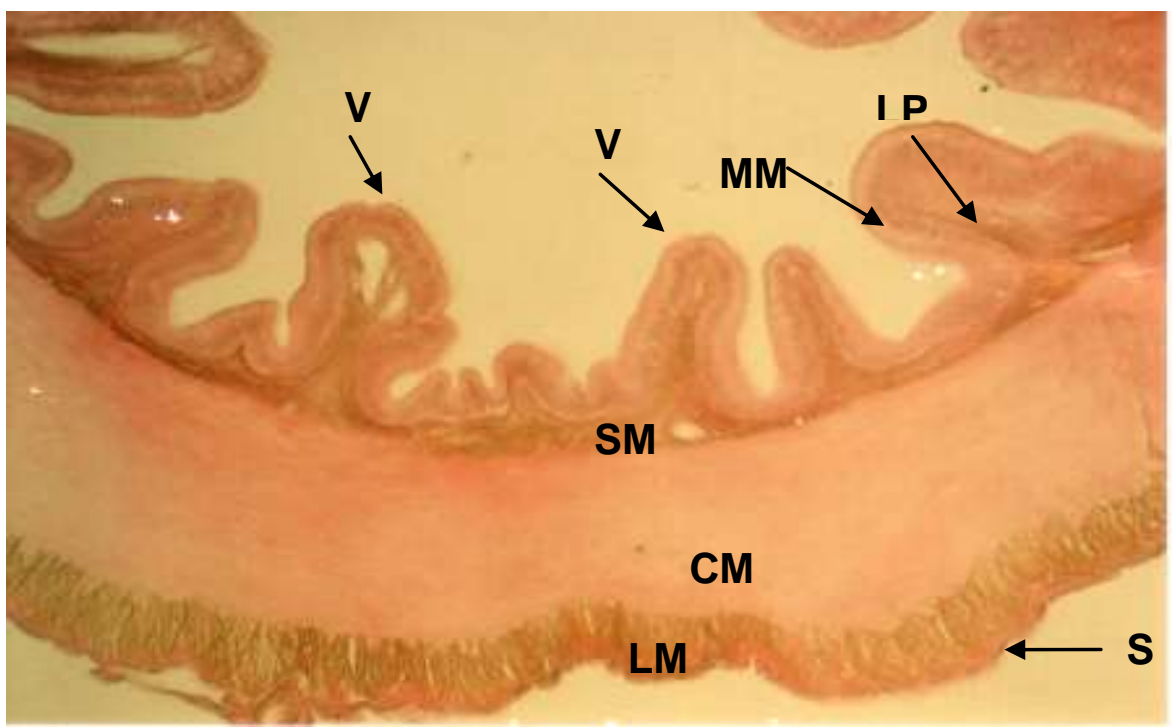

PLATE 1: PHOTOMICROGRAPH OF THE SECTION OF INTESTINE OF CLARIAS BATRACHUS OF CONTROL SPECIMEN SHOWING VILLI (V), MUCOSAL MEMBRANE (MM), LAMINA PROPRIA (LP), SUBMUCOSA (SM), MUSCULARIS COMPRISING CIRCULAR MUSCLE LAYER (CM) AND LONGITUDINAL MUSCLE LAYER (LM), AND SEROSA (S). H\&E $10 \times 10$.

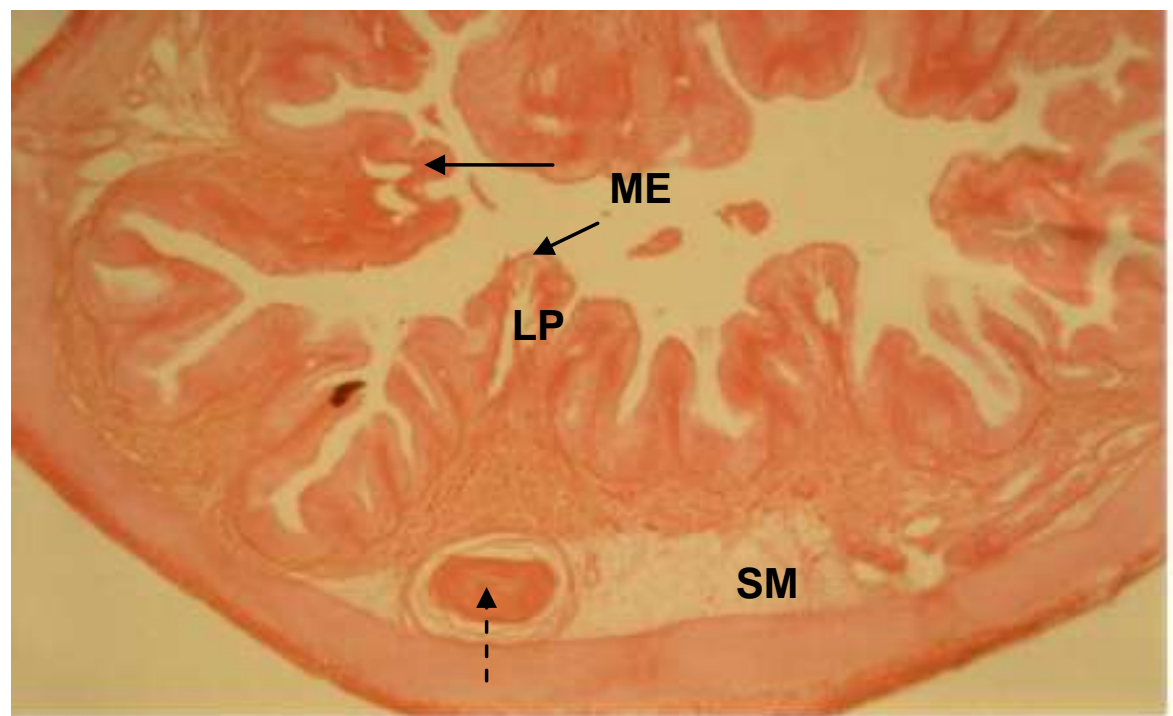

PLATE 2: PHOTOMICROGRAPH OF THE SECTION OF INTESTINE OF CD-EXPOSED CLARIAS BATRACHUS SHOWING DETACHMENT OF THE MUCOSAL EPITHELIUM (ME) FROM THE BASAL LAYER; VACUOLATION AND CONGESTION OF BLOOD IN LAMINA PROPRIA (LP) AND SUBMUCOSA (SM); AND A TUMOUR LIKE GROWTH (ARROW) IN SUBMUCOSA. H\&E 10×10. 


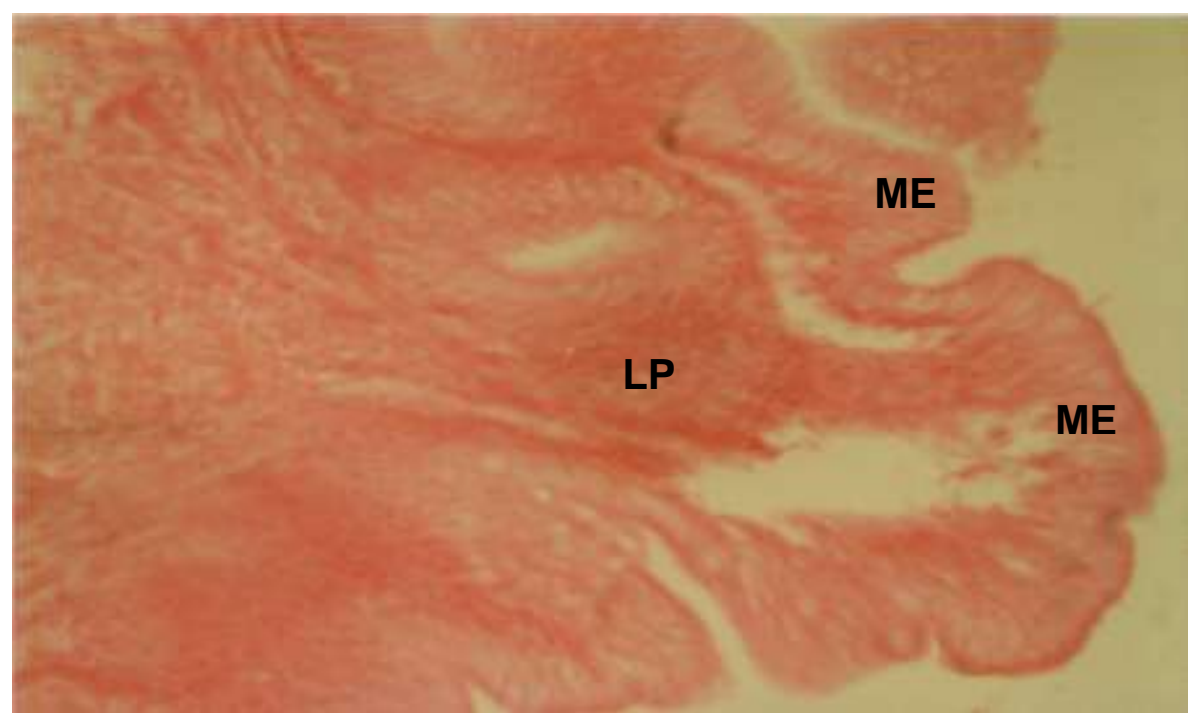

PLATE 3: PHOTOMICROGRAPH OF THE SECTION OF INTESTINE OF CD-EXPOSED CLARIAS BATRACHUS SHOWING SEPARATION OF MUCOSAL EPITHELIUM (ME) CONTAINING HYPERTROPHIED EPITHELIAL CELLS AND GOBLET CELLS AND CONGESTION OF BLOOD IN LAMINA PROPRIA (LP). H\&E 10×40.

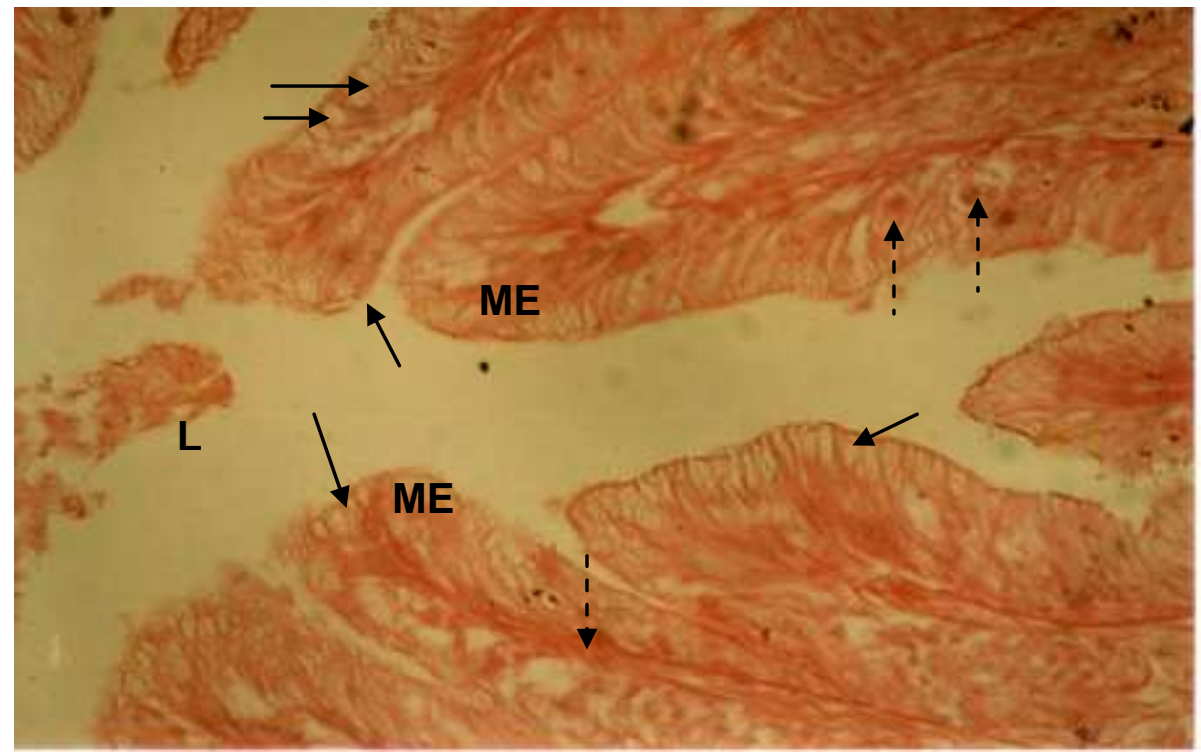

PLATE 4: PHOTOMICROGRAPH OF THE SECTION OF INTESTINE OF CR-EXPOSED CLARIAS BATRACHUS SHOWING HYPERTROPHIED EPITHELIAL CELLS WITH CLEAR CYTOPLASM OF MUCOSAL EPITHELIUM(ME), DISARRANGEMENT OF THE EPITHELIAL CELLS, INCREASED NUMBER OF GOBLET CELLS (ARROW), SLOUGHED OFF EPITHELIAL CELLS WITH MUCOUS IN THE LUMEN (L) OF INTESTINE AND NECROSIS IN MUCOSAL LAYER (BROKEN ARROW). H\&E 10×10. 
BEUM ET AL.

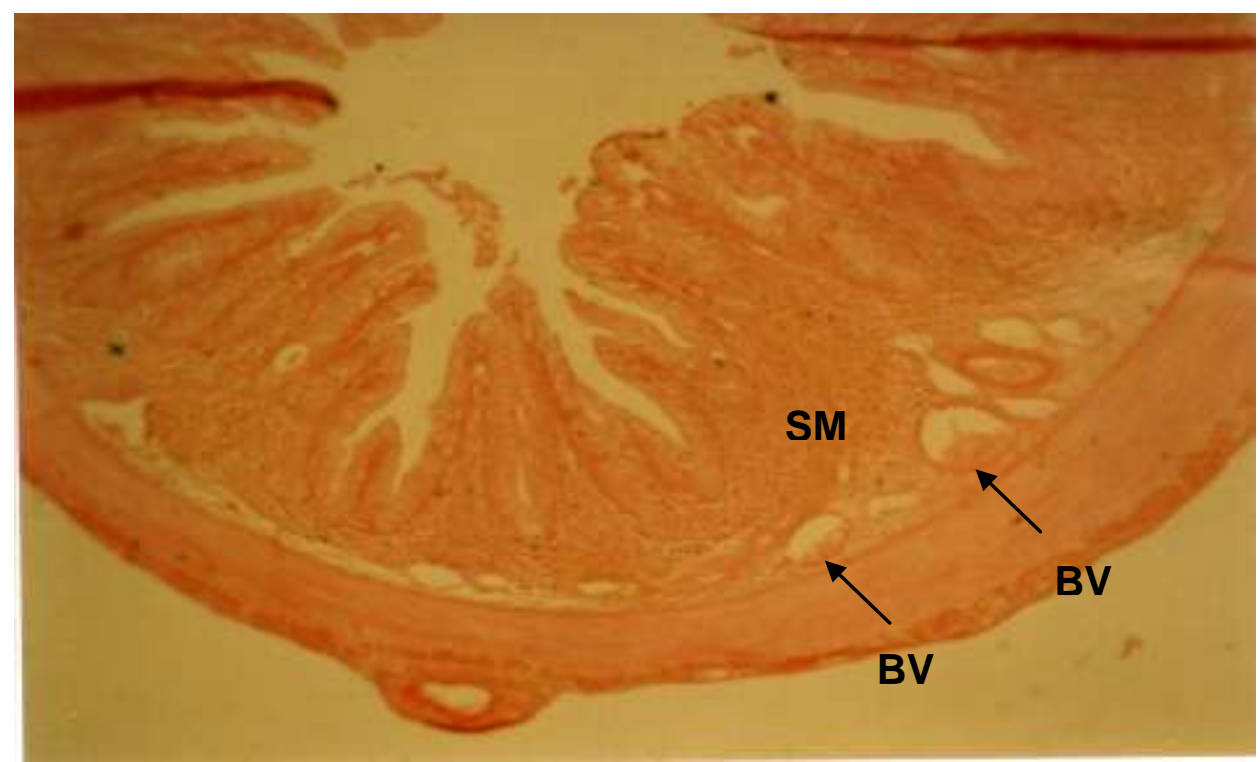

PLATE 5: PHOTOMICROGRAPH OF THE SECTION OF INTESTINE OF CR-EXPOSED CLARIAS BATRACHUS SHOWING DEGENERATION OF CONNECTIVE TISSUE OF SUBMUCOSA (SM) AND DILATED BLOOD VESSELS (BV). H\&E 10×10.

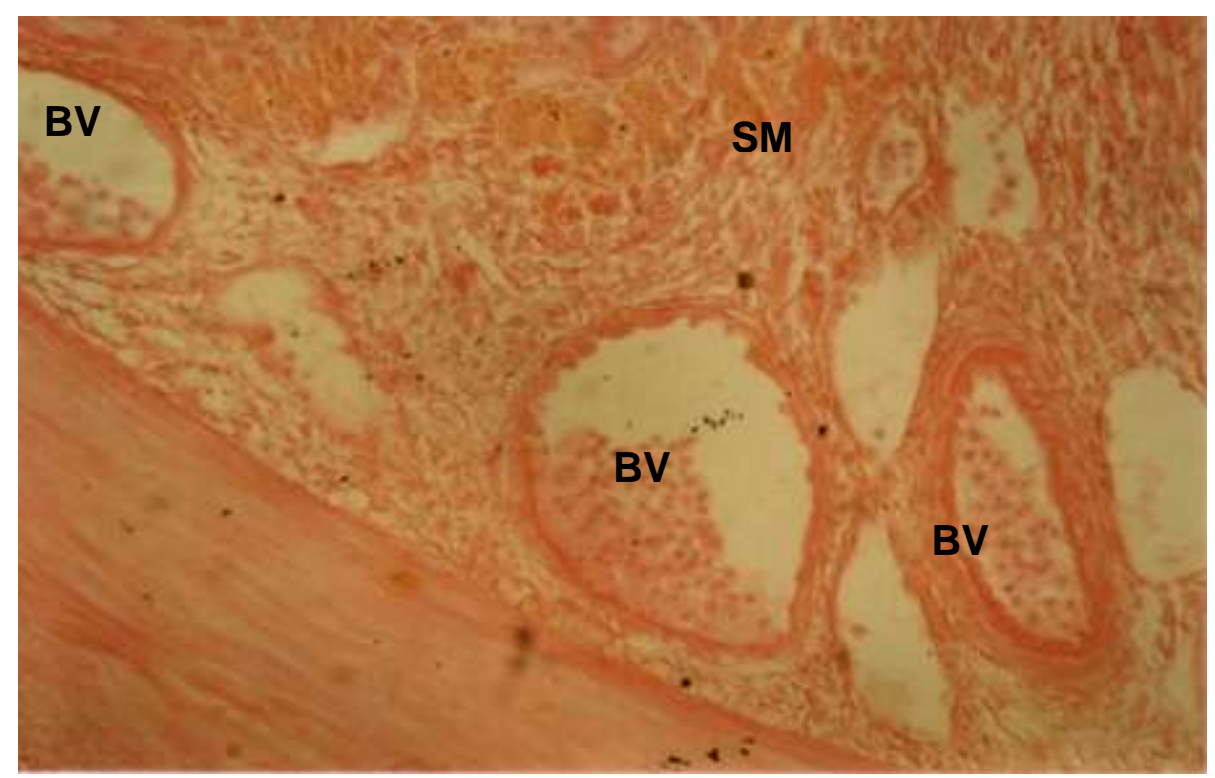

PLATE 6: PHOTOMICROGRAPH OF THE SECTION OF INTESTINE OF CR-EXPOSED CLARIAS BATRACHUS SHOWING DEGENERATION OF CONNECTIVE TISSUE OF SUBMUCOSA (SM) FORMING CLUSTERS AND DILATED BLOOD VESSELS (BV) WITH EXCESS BLOOD CELLS. H\&E 10×40. 


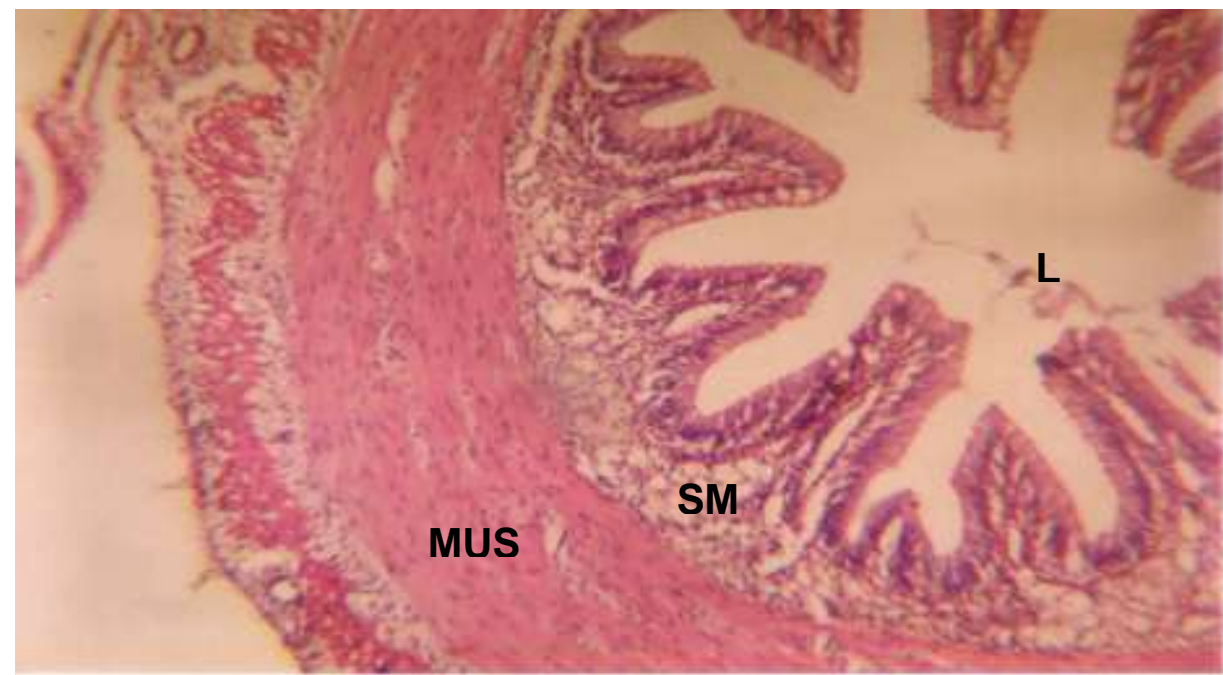

PLATE 7: PHOTOMICROGRAPH OF THE SECTION OF INTESTINE OF HG-EXPOSED CLARIAS BATRACHUS SHOWING MUCOUS IN THE LUMEN (L) OF INTESTINE, DISTORTED CONNECTIVE TISSUE OF SUBMUCOSA (SM), RUPTURE IN MUSCLE LAYER (MUS) AND SCATTERED BLOOD CELLS ALL OVER THE TISSUE. H\&E 10×10.

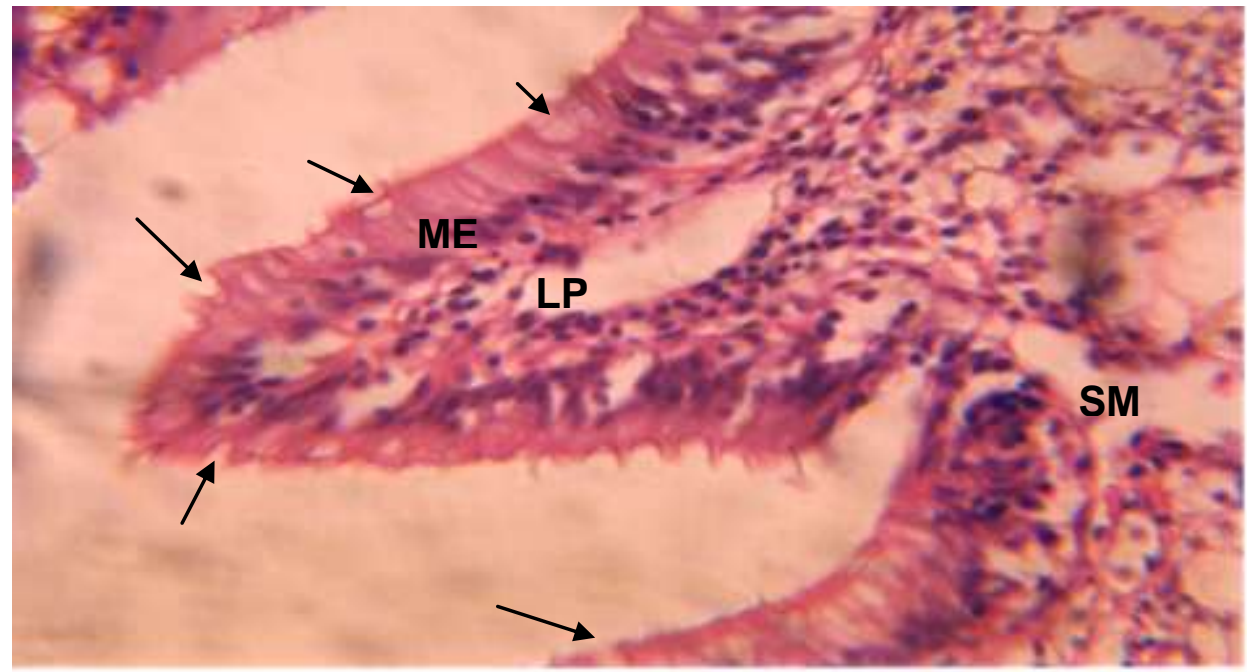

PLATE 8: PHOTOMICROGRAPH OF THE SECTION OF INTESTINE OF HG-EXPOSED CLARIAS BATRACHUS SHOWING EXTENSIVE DAMAGE OF THE MUCOSAL EPITHELIAL CELLS WHICH WERE HYPERTROPHIED WITH PYKNOTIC NUCLEI; RUPTURED AND NECROSED MUCOSAL EPITHELIUM (ME), MANY GOBLET CELLS (ARROW), AND DISTORTED LAMINA PROPRIA (LP) AND SUBMUCOSA (SM). H\&E $10 \times 40$.

Manuscript received on 31. 3. 2010; Accepted on 29.9.11

The Chittagong University Journal of Biological Sciences, Vol. 5 (1 \& 2). Page No:45-53 